\title{
A study of Crohn's syndrome using tissue extracts and the Kveim and Mantoux tests
}

\author{
W. JONES WILLIAMS \\ From the Institute of Pathology, Welsh National School of Medicine, \\ the Royal Infirmary, Cardiff
}

EDITORIAL SYNOPSIS The inference from these studies is that tuberculosis, sarcoidosis, and hyposensitivity reactions are not related to the aetiology of Crohn's syndrome.

Fifty patients with Crohn's syndrome and 20 with ulcerative colitis were investigated in an attempt to assess the possible antigenic activity of Crohn's tissue extracts as determined by skin testing and precipitin reactions; the response to Kveim testing in Crohn's syndrome; the Mantoux state in Crohn's cases compared with that in ulcerative colitis; the correlation between the Mantoux state with $(a)$ the histological type of Crohn's syndrome and $(b)$ with the severity of inflammation in ulcerative colitis.

I suggested in 1963 that skin testing with extracts of Crohn's tissue might be worthwhile on the analogy of the Kveim test in sarcoidosis. The histology of Crohn's tissue may be subdivided into two main groups, with and without focal (sarcoid-like) granuloma (Williams, 1964). On this analogy the Crohn's extracts were prepared from tissue showing focal granuloma and the tests were only made on patients with negative Mantoux reactions.

\section{MATERIALS AND METHOD}

The 50 patients with Crohn's syndrome and 20 with ulcerative colitis all showed the classical clinical, radiological, and pathological features of the conditions. No fulminating cases of ulcerative colitis were included. Patients receiving cortisone were excluded. Whenever possible the skin tests were made before operation and only those whose pathology confirmed the diagnosis were included in the trial. If the diagnosis was not made or not confirmed until after major surgery, the tests were done seven to 10 days post-operatively, as skin sensitivity may be depressed following operations. In a few cases the tests were performed on patients with recurrence and known clinical and pathological evidence of previous disease.

Crohn's tissue extracts were prepared by the method used for the preparation of Kveim antigen (Nelson, 1948), with the exception that the final dilution was 1 in 10 and not 1 in 20. Fresh specimens of diseased ileum, colon, and lymph glands were used. In the case of the gut a full- thickness piece was taken, including serosal fat. This was washed in running water to eliminate gross contamination with intestinal content and cut in two; one part was used for histological examination and the other was deep frozen pending processing and only those cases showing focal granuloma were used. The final coarse, flocculent tissue suspensions were rigorously tested for sterility, including guinea-pig inoculation to exclude tuberculosis. Tubercle bacilli were not found in any of the material. The total number of extracts produced were four of colon, four of ileum, and six from ileocaecal glands. Material from each site was pooled and $0.1 \mathrm{ml}$. of the three types injected separately into the skin of the forearm at defined sites. The injection was made into the superficial subcutaneous tissue, as, in my own experience of Kveim testing, this is the best site for the production of granuloma.

Precipitin tests were performed by the gel diffusion method (Dumbell and Nizamuddin, 1959), using the pooled Crohn's extracts from the three sites. These were tested against the sera from 13 cases of Crohn's syndrome, which were also tested against tissue extract of normal colon, ileum, and ileocaecal glands.

The Kveim antigen $(0 \cdot 1 \mathrm{ml}$.) was injected into the superficial subcutaneous tissue at a marked site on the forearm. The antigen was obtained from the Public Health Laboratory at Colindale and was of proven potency, having been previously tested in established cases of systemic sarcoidosis.

The Mantoux tests were done by the intradermal injection of $0.1 \mathrm{ml}$. of $1 / 1000$ O.T. Varidase (Lederle Laboratories) containing 20,000 units of streptokinase and 5,000 units of streptodornase, was used as a control.

The severity of inflammation in ulcerative colitis was graded from I to III; I the colon was least affected; III showed extensive ulceration with inflammation extending throughout the bowel wall; and II was of intermediate severity.

\section{RESULTS}

CROHN'S SYNDROME Crohn's extract skin tests were done in 13 patients and produced a transient 
erythema which disappeared in four to six hours, but no nodule, despite inspection at intervals of 48 hours two, four, and six weeks. To visualize any nodule the site was moistened with alcohol and observed in incident light. Control injections in five normal patients showed similar transient erythema and no nodulation. As there were no nodules biopsy of the sites was not done.

No precipitins were detected in the sera of 13 patients tested against extracts of normal and Crohn's ileum, colon, and lymph nodes.

The Kveim test was performed on 14 Mantouxnegative patients with no positive response. A faint blush appeared in $10 \mathrm{~min}$., which faded in approximately four hours. No nodule was seen on careful examination after intervals of $\mathbf{4 8}$ hours, two, four, and six weeks and no biopsies were done.

Table I shows the results of Mantoux testing in 50 patients with Crohn's syndrome; 32 (64\%) were Mantoux negative and $18(36 \%)$ Mantoux positive. It is seen that those cases with focal granuloma show a higher incidence of negative results ( 18 of $23,78 \%$ ) than do those without focal granuloma (14 of 27, $51 \%$ ). It is also seen that the incidence of focal granuloma in this series approximates to $50 \%$, which agrees with a previous analysis (Williams, 1964). Many of the present cases were not included in the previous analyses. Varidase controls were performed on seven of the patients who had negative Mantoux reactions and all were positive.

TABLE I

HISTOLOGY OF CROHN'S SYNDROME RELATED TO THE MANTOUX REACTION

\begin{tabular}{llcc} 
Focal Granuloma & $\begin{array}{l}\text { No. of } \\
\text { Cases }\end{array}$ & \multicolumn{2}{c}{ Mantoux Reaction } \\
\cline { 3 - 4 } & & + & - \\
\hline With & 23 & 5 & 18 \\
Without & 27 & 13 & 14 \\
Total & 50 & 18 & 32
\end{tabular}

ULCERATIVE COLITIS The results of the Mantoux tests in 20 cases are seen in Table II (11 negative, $55 \%$; nine positive, $45 \%$ ). Varidase controls were made in 10 instances; five were negative and five

\section{TABLE II}

HISTOLOGY OF ULCERATIVE COLITIS RELATED TO THE MANTOUX REACTION

\begin{tabular}{lccc} 
Grade of Inflammation & $\begin{array}{c}\text { No. of } \\
\text { Cases }\end{array}$ & \multicolumn{2}{c}{ Mantoux Reaction } \\
\cline { 3 - 4 } & & + & - \\
\hline I & 3 & 2 & 1 \\
II & 6 & 1 & 5 \\
III & 11 & 6 & 5 \\
All grades & 20 & 9 & 11
\end{tabular}

were positive and corresponded to the respective negative and positive Mantoux tests. Though the numbers are too few to draw definite conclusions, it does not appear that increasing severity of inflammation leads to increased incidence of negative reactions. There is no significant difference between the overall incidence of negative reactions in ulcerative colitis (55\%) and in Crohn's syndrome $(64 \%)$.

\section{DISCUSSION}

It was hoped that skin testing with extracts of Crohn's tissue would have served as a comparable diagnostic test to the Kveim test in sarcoidosis. However, 13 cases tested with extracts from ileum, colon, and lymph nodes showed no positive response. Seven were also tested with Varidase and all gave a positive reaction and it was therefore considered that they were all capable of reacting to possible antigens. Further none of the test cases were receiving cortisone, which is known to inhibit the Kveim test (Anderson, James, Peters, and Thomson, 1963). It must be presumed therefore that the extracts were not antigenic. Sanders (1964) skin tested nine patients with a lymph node extract also with negative results, but, as only four had active disease and these were also receiving cortisone treatment, his negative results may not be surprising. Further Sanders did not describe the histology of the lesion in the patients tested and apparently his extracts were not made from glands with focal, sarcoid-like granuloma.

Broberger and Perlmann (1959) state that sera from 22 of 30 patients with ulcerative colitis showed precipitins against normal colon. Twenty per cent of their cases showed focal granuloma from which I infer that they included some cases classifiable as of Crohn's disesae. It was therefore considered worthwhile to repeat this investigation with sera from patients with Crohn's disease with focal granuloma. In the 13 tested it was negative using normal and diseased organs. Koffler, Minkowitz, Rothman, and Garlock (1962) also failed to demonstrate antibodies in 25 cases of Crohn's disease, using the indirect fluorescent technique. Although it is often maintained (Slaney, 1961) that the granulomatous component of Crohn's syndrome is an expression of hypersensitivity and possibly of autoimmunity, at the moment there is no definite proof.

The uniformly negative Kveim test in 14 patients favours the distinction of Crohn's syndrome from sarcoidosis, as in the latter the test is positive in $86 \%$ (Siltzbach and Ehrlich, 1954). Together with the accepted clinical distinctions (Longcope and Freiman, 1952), and, despite some confusing similar 
features, the Kveim test is very strong evidence for separation of the two syndromes.

The high incidence of negative Mantoux reactions in Crohn's syndrome has been confirmed. In an earlier series of 24 cases (Williams, 1963), the incidence was $67 \%$ and now with an additional 26 cases the incidence is $64 \%$. Blackburn, Hadfield, and Hunt (1939) and Phear (1958) gave an incidence of between $70 \%$ and $80 \%$.

The Mantoux tests were done in ulcerative colitis, as no figures had been found in the literature, and to answer possible criticisms of the results in cases of Crohn's disease that any extensive inflammatory intestinal disease causes non-specific depression of skin sensitivity, also to assess the possible value of the Mantoux test in distinguishing cases of colonic Crohn's disease from ulcerative colitis. The incidence of $64 \%$ negative Mantoux reactions in cases of Crohn's disease does not appear to be a general depression of skin sensitivity, as all of the seven cases tested with Varidase gave a positive reaction. However, in Mantoux-negative cases of ulcerative colitis the Varidase test was only positive in half (five out of 10) which suggests that the remaining five showed general depression of all skin sensitivity. These results imply that there is a more specific depression of Mantoux activity in Crohn's syndrome than in ulcerative colitis. The overall incidence of Mantoux-negative reactions in Crohn's syndrome $(64 \%)$ and in Crohn's syndrome without focal granuloma $(51 \%)$ is not significantly different from that in ulcerative colitis $(55 \%)$. However, there is a definite difference $(78 \%)$ on considering Crohn's cases with focal granuloma. The only available figures of the Mantoux incidence in a large population are those of Hart, Cochrane, and Higgins (1963) who found that miners of all ages with or without pneumoconiosis showed a negative incidence of $12.3 \%$ and that this was unrelated to the presence or degree of dust disease. The figures for Crohn's syndrome and ulcerative colitis are significantly higher than in this special population and are probably much higher than in the general population.

The figure of $78 \%$ in Crohn's cases with focal granuloma is very similar to the incidence of negative reactions in generalized sarcoidosis, though it is agreed and generally accepted that the two syndromes do not overlap and are clinically distinct. However, they show two other features in common, non-caseating granulomata and absent tubercle bacilli. In view of the latter finding and the high incidence of negative Mantoux reactions in both syndromes, aetiological research should be concentrated on agents other than on tubercle bacilli.

\section{CONCLUSIONS}

The Kveim test in Crohn's syndrome is negative. In patients with Crohn's syndrome skin testing and precipitin reactions with extracts of Crohn's tissue from other cases of Crohn's disease were also negative.

The overall incidence of negative Mantoux reactions in 50 cases of Crohn's syndrome is $64 \%$; in cases with focal, i.e., sarcoid-like, granuloma it is $78 \%$ and without focal granuloma $51 \%$.

Fifty-five per cent of 20 cases of ulcerative colitis were Mantoux negative and the incidence was apparently unrelated to the severity of the inflammation.

The increased incidence of Mantoux-negative reactions in Crohn's syndrome as compared to ulcerative colitis appears to be associated with focal granuloma.

The results, though not offering any new theories, suggest that tuberculosis, sarcoidosis, and probably hypersensitivity reactions are not concerned in the aetiology of Crohn's syndrome.

I wish to express my thanks to many surgeons and physicians at St. Mark's Hospital, London, Mount Vernon Hospital, and the Royal Infirmary, Cardiff, for access to their patients. I am grateful to Miss Dihgero, of the Public Health Laboratory Service, Colindale, for preparing the Crohn's tissue extract.

\section{REFERENCES}

Anderson, R., James, D. G., Peters, P. M., and Thomson, A. D. (1963). The Kreim test in sarcoidosis. Lancet, 2, 650-653.

Blackburn, G., Hadfield, G., and Hunt, A. H. (1939). Regional ileitis. St. Bart. Hosp. Rep., 72, 181-224.

Broberger, O., and Perlmann, P. (1959). Autoantibodies in human ulcerative colitis. J. exp. Med., 110, 657-674.

Dumbell, K. R., and Nizamuddin, M. (1959). An agar-gel precipitin test for the laboratory diagnosis of smallpox. Lancet, 1, 916-917.

Hart, J. T., Cochrane, A. L., and Higgins, I. T. T. (1963). Tuberculin sensitivity in coal workers' pneumoconiosis. Tubercle (Edinb.), 44, 141-152.

Koffler, D., Minkowitz, S., Rothman, W., and Garlock, J. (1962). Immunocytochemical studies in ulcerative colitis and regional ileitis. Amer. J. Path., 41, 733-745.

Longcope, W. T., and Freiman, D. G. (1952). A study of sarcoidosis: based on a combined investigation of 160 cases including 30 autopsies from the Johns Hopkins Hospital and Massachusetts General Hospital. Medicine (Baltimore), 31, 1-132.

Nelson, C. T. (1948). Observations on the Kveim reaction in sarcoidosis of the American Negro. J. invest. Derm., 10, 15-26.

Phear, D. N. (1958). The relation between regional ileitis and sarcoidosis. Lancet, 2, 1250-1251.

Sanders, R. C. (1964). An attempt to devise a skin test for regional enteritis. Gut, 5, 194-195.

Siltzbach, L. E., and Ehrlich, J. C. (1954). The Nickerson-Kveim reaction in sarcoidosis. Amer. J. Med., 16, 790-803.

Slaney, G. (1961). Alimentary granulomata and the immune response. Postgrad. med. J., 37, 276-281.

Williams, W. J. (1963). The laboratory diagnosis of Crohn's syndrome. Proc. roy. Soc. Med., 56, 490.

_ (1964). Histology of Crohn's syndrome. Gut, 5, 510-516. 